\begin{tabular}{|l|l|l|}
\hline \multicolumn{2}{|c|}{ PublisherInfo } \\
\hline \hline PublisherName & $:$ & BioMed Central \\
\hline \hline PublisherLocation & $:$ & London \\
\hline \hline PublisherImprintName & $:$ & BioMed Central \\
\hline \hline
\end{tabular}

\title{
DAP12 and dendritic cells
}

\begin{tabular}{|l|l|l||}
\hline \multicolumn{2}{|c|}{ ArticleInfo } \\
\hline \hline ArticleID & $:$ & 3669 \\
\hline \hline ArticleDOI & $:$ & $10.1186 /$ gb-2000-1-6-reports0080 \\
\hline \hline ArticleCitationID & $:$ & reports0080 \\
\hline \hline ArticleSequenceNumber & $:$ & 19 \\
\hline \hline ArticleCategory & $:$ & Paper report \\
\hline \hline ArticleFirstPage & $:$ & 1 \\
\hline \hline ArticleLastPage & $:$ & 4 \\
\hline \hline & & RegistrationDate : 2000-11-8 \\
ArticleHistory & $:$ & Received \\
\hline \hline ArticleCopyright & $:$ & BioMed Central Ltd2000-11-8 \\
\hline \hline ArticleGrants & $:$ & \\
\hline \hline
\end{tabular}




\begin{tabular}{|l|l|l|}
\hline ArticleContext & $:$ & 130591166 \\
\hline
\end{tabular}

\section{Rachel Allan}

\section{Abstract}

Characterization of immune system abnormalities in mice deficient for the transmembrane adaptor protein DAP12 is described.

\section{Significance and context}

Because they lack signaling capacity, certain immune-cell receptors mediate their responses through association with 'adaptor' proteins such as DAP12 and CD3 $\zeta$. DAP12 was first characterized by its association with the activating immunoglobulin-like receptors of human natural killer (NK) cells and the equivalent Ly49D and Ly49H receptors in mice. It is, however, also expressed in monocytes, macrophages and dendritic cells, and appears to engage a wide variety of receptors. Known associated receptor chains include MDL-1 and SIRP $\alpha$ in myeloid cells, TREM1 in neutrophils/monocytes and SIRP $\alpha$ and TREM2 in dendritic cells. Attention is therefore now focused on unraveling the multiple physiological roles of DAP12. Here, Tomasello et al. describe the generation and characterization of DAP12-deficient mice and address the functional importance of this protein in vivo. The most profound effects were seen not, as might have been predicted, in NK cells, but in dendritic cell populations.

\section{Key results}

Knock-in mice expressing a non-functional DAP12 mutant were generated using standard homologous recombination and embryonic stem cell techniques. Reverse-transcriptase-coupled-PCR (RT-PCR) confirmed that these mice were homozygous for the mutant gene, and that the integrity of flanking genes was maintained. DAP12 mutant mice developed normally, with no significant alteration in the levels of lymphoid and myeloid cell subsets in their peripheral blood. The lytic capacity of their NK cells was assessed by killing assays in vitro. Lysis mediated specifically by the DAP12-associated NK receptor Ly49D was severely impaired, although alternative killing systems (dependent on other transmembrane adaptors) remained intact. It has previously been suggested that activating receptors such as Ly49D and Ly49H might regulate the expression of their inhibitory isoforms. Flow cytometric analysis of NK cells from DAP12 mutant mice revealed a normal inhibitory receptor repertoire, however, indicating that NK cell differentiation was not affected. The most significant effects of DAP12 deficiency were apparent in dendritic cell populations. Although no detectable changes in dendritic cell populations in lymphoid organs were observed, immunohistochemical staining of lympho-epithelial 
tissues revealed striking abnormal accumulations of dendritic cells in the mucosa of the small intestine, the dermis of buccal epithelia and the dermis of the skin. No gross deficiencies were observed in the phenotype of DAP12-deficient dendritic cells, their migratory capacity or their ability to stimulate allogeneic CD4 T cells, but they were unable to prime hapten-specific CD8 T cells in a contactsensitivity test.

\section{Links}

A related paper describing the failure of DAP12-deficient mice to develop autoimmunity appeared in the same issue of Immunity and is available to subscribers.

\section{Conclusions}

The authors conclude that DAP12 must have a critical role in myeloid dendritic cell/pre-dendritic cell differentiation and/or activation, although the mechanisms underlying this function remain obscure.

\section{Reporter's comments}

As expected, DAP12-associated NK receptors could not function in mice that lacked this adaptor protein. Natural killing involves multiple receptors, however, of which only a subset associate with DAP12. Circulating NK cells therefore appeared to be grossly normal in the mutant mice. In contrast, two unusual features of dendritic cells were observed for DAP12-deficient mice. Dendritic cells are highly specialized antigen-presenting cells which capture antigen in the periphery and carry it to draining lymph nodes. Tomasello et al. found that dendritic cells accumulate in lympho-endothelial tissues of DAP12-deficient mice, and are unable to prime hapten-specific T cells. The pathway(s) that might link DAP12 to the T-cell priming function of dendritic cells remains a mystery; it also remains to be seen whether their failure to prime is related to their accumulation in peripheral tissues. DAP12 is known to associate with SIRP $\alpha 1$, TREM-1, TREM-2 and MDL-1 and it is likely that other co-receptors have yet to be identified. Characterization of DAP12-associated receptors will cast fresh light on the network of pathways that rely on this adaptor for signal transduction.

\section{Table of links}

Immunity 


\section{References}

1. Tomasello E, Desmoulins P-O, Chemin K, Guia S, Cremer H, Ortaldo K, Love P, Kaiserlian D, Vivier E: Combined natural killer cell and dendritic cell functional deficiency in KARAP/DAP12 lossof-function mutant mice. Immunity. 2000, 13: 355-364. 1074-7613

This PDF file was created after publication. 